\title{
スプライン軸における破壊力学的挙動*
}

\section{Destruction Phenomenon about the Spline Shaft} \\ Tetsuo NOGUCHI*3 and Tsutomu EZUMI \\ ${ }^{* 3}$ Researcher in Shibaura Institute of Technology, \\ 3-7-5 Toyosu, Koutou-ku, Tokyo, 135-8548 Japan
}

野口哲 雄*1, 江 角

務*2

\begin{abstract}
A spline is a stretchable joint that transmits power. Generally, for the fracture problem in an actual construction, three-dimensional cracks exist in most cases, and in crack propagation, the stress intensity factors $K_{\mathrm{I}}, K_{\mathrm{II}}$ and $K_{\mathrm{III}}$ usually act in single or mixed modes. In this study, the maximum stress and maximum stress direction are determined by the photoelastic and finite element methods. The mixed modes stress intensity factors $K_{\mathrm{I}}, K_{\mathrm{II}}$ and $K_{\mathrm{III}}$ are determined experimentally by combining the caustic method and photoelastic stress freezing method. The interaction in the spline shaft having outer surface crack was also discussed, together with a comparison of the results of these experimental methods.
\end{abstract}

Key Words: Experimental Stress Analysis, Stress Concentration, Finite Element Method, Photoelastic Method, Method of Caustics, Spline

1. 緒

軸方向に伸縮性を有する軸継手としてスプライン継 手が知られている．動力を伝達する機械要素として重 要な役割を担っているが，破壊力学的挙動について未 知なる部分が多い. 過去において光弾性法によるスプ ライン軸の応力解析 ${ }^{(1)}$, ねじり負荷を受けるスプライ ン状横断面を有する軸に関する研究 ${ }^{(2)}$ が見られる。し かし金属疲労にともなうき裂を想定した研究 ${ }^{(3)}$ は少な く，スプライン軸に関する破壊力学的検討の必要性が 認められる. 本研究室は 1997 年よりスプライン軸に ついて研究を続けている. 本論文においてスプライン 軸に関する破壊力学的挙動を報告する.

本研究は次に示す 3 項目により構成される.

（1）スプライン軸モデルを製作し，最大応力と最大応 力方向を求めた.

（2）金属疲労によりき裂が発生した状態を再現するた めに，(1)において求められた最大応力方向に人工き 裂を挿入し, 応力拡大係数を求めた。

（3）一般的にスプライン軸は酎摩耗性を向上させるた めに熱処理が施される. 熱処理を施す際, 材料表面と 材料内部における温度差により焼き割れが発生する可 能性がある．焼き割れを再現したモデルとして，外周 面から中心方向に人工き裂を挿入したモデルを用意

* 原稿受付 2006 年 6 月 12 日.

*1 正員, 芝浦工業大学応用力学研究室(业 135-8548 東京都江 東区豊洲 3-7-5).

*2 正員, 芝浦工業大学工学部.

E-mail : nasubi@a.toshima.ne.jp
し, 応力拡大係数を求めた。予備実験として外周部に 軸方向き裂を有する円形断面実軸モデルにねじり負荷 を与え, 反射型コースティックス法を適用し, 応力拡 大係数算定の有効性を調べた.

\section{2. 実 䀫 方 法}

\section{2・1 スプライン軸に関する応力解析 型取用シ} リコンゴム (Recipron 1406,Temuco Fine)に硬化剂 （R-14,Temuco Fine）を混合し，角形スプライン(呼び 径 32mm,みぞ数 8,2 形,JS B 1601) を有する軸とボス を型取りすることにより鋳型を製作した．エポキシ樹 脂 (Araldite B,CT-200) と硬化剂（Hardner HT-901）を容 器内において $120 \sim 130{ }^{\circ} \mathrm{C}$ に加熱し, 混合した. 溶 融したエポキシ樹脂 ${ }^{(4)}$ を製作した鋳型に注入し，温風 乾燥炬により熱硬化し，アニーリングを施すことによ り，スプライン軸モデル(図 1),スプラインボスモデ ル(図 2)を製作した.エポキシ樹脂の特性值を表 1 に 亦す. スプラインボスモデルにスプライン軸モデルを 挿入し，図 3 に示す静的ねじり試験機に取り付けた。 静的ねじり試験機はてこ棒を有しており，てこ棒先端 におもりを吊り下げることにより，試験片モデルにね じりモーメントを与える. おもりにより得られる荷重 は $9.8 \mathrm{~N}$ であり, 荷重により得られるねじりモーメン トは $1.764 \mathrm{~N} \cdot \mathrm{m}$ である. 静的ねじり試験機に取り付け た試験片モデルを温風乾燥炉内に設置し, 図 4 に示 す応力凍結サイクルによる光弾性応力凍結法を適用し た. 応力凍結後, 図 5 に示す位㯰においてスライス し, スライス面を研磨した. スライス片に光弾性法を 
適用し，最大応力と最大応力方向を求めた.

信頼性を高めるために，同様に有限要素法により応 力集中位置を求めた。図 6 に有限要素解析モデルを 示す. 統合型有限要素解析システム (Free Femleeg,木
クト・システム)により静的弾性解析を試みた。

$2 \cdot 2$ スプライン軸に関する破壊力学的挙動 長期 間の使用による金属疲労によりき裂が発生した状態を 再現するために, 図 7 に示す人工き裂を挿入したス

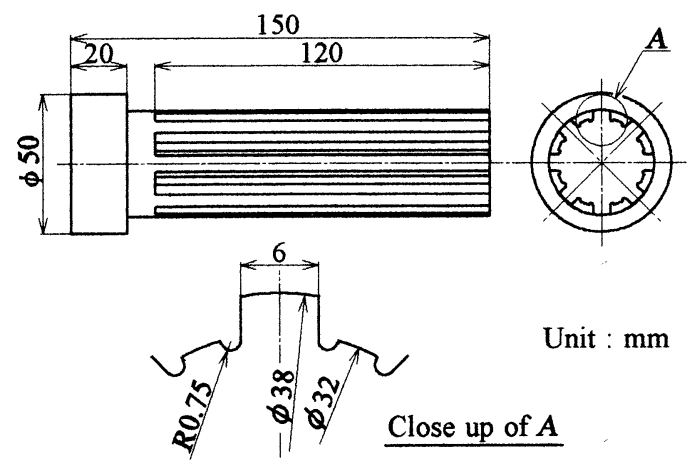

Fig.1 Spline shaft model
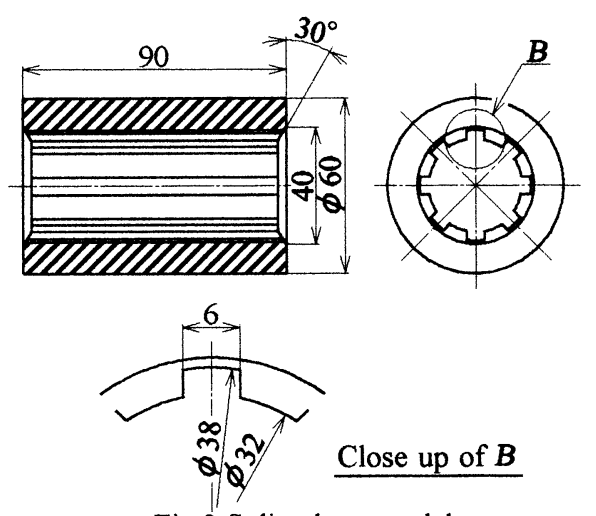

Fig. 2 Spline boss model

Table 1 Epoxy resin data

\begin{tabular}{c|c|c}
\hline \hline Temperature & Young's Modulus [MPa] & Poisson's ratio \\
\hline Room temperature & 3000 & 0.33 \\
\hline $125^{\circ} \mathrm{C}$ & 13.62 & 0.45 \\
\hline
\end{tabular}

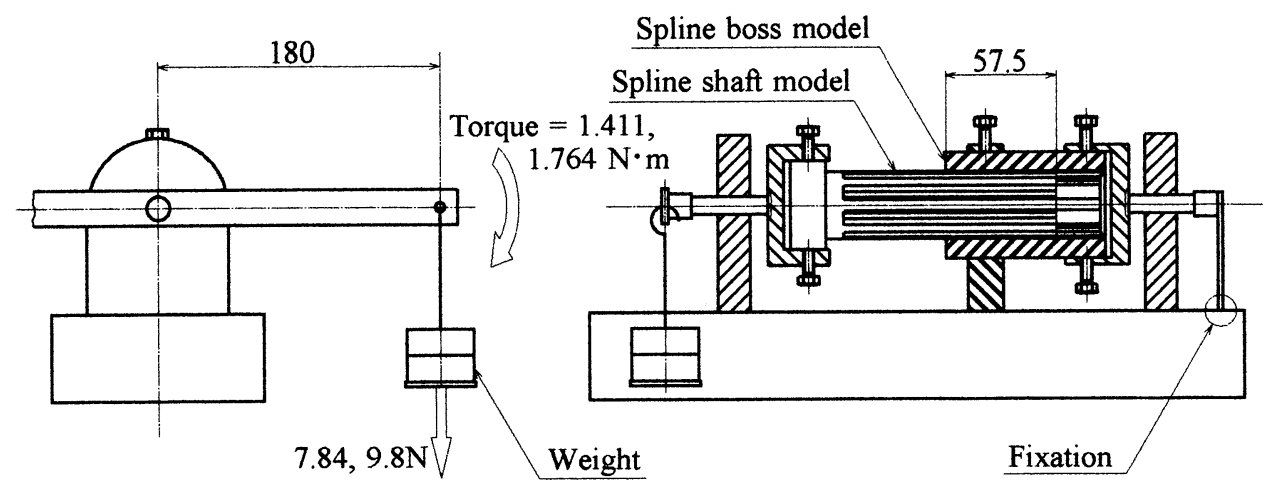

Fig. 3 Testing system for spline model

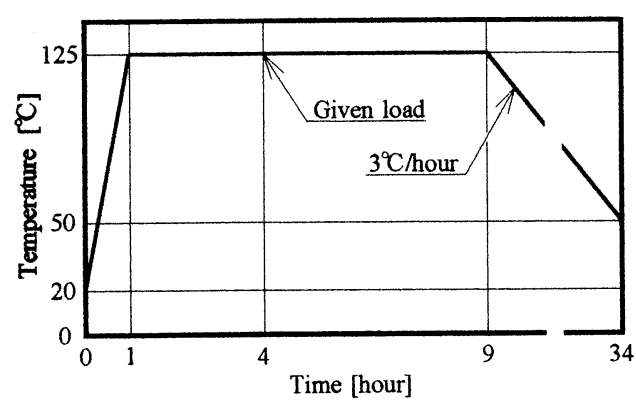

Fig.4 Stress freezing cycle

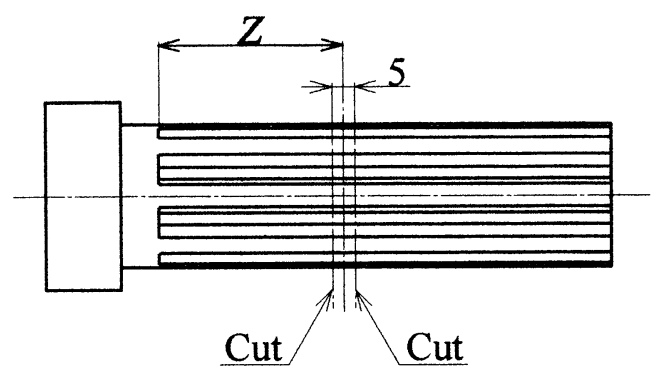

Fig. 5 Slice location 


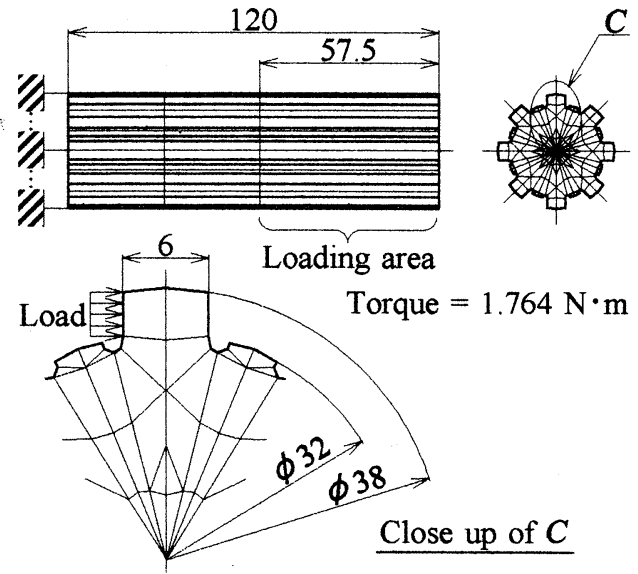

Fig. 6 Fnite element model

プライン軸モデルを $2 \cdot 1$ と同様に製作した．図 7 に 示すように，スプライン軸中心とスプラインみぞ底円 弧部中心を結ぶ直線を基準 $\left(0^{\circ}\right)$ とし，55方向に人 工き裂を挿入した． $2 \cdot 1$ において求められた最大応力 方向はスプライン軸中心方向に対して $55^{\circ}$ であるこ とより，550方向に人工き裂を挿入した，き裂挿入方 法として，メタルソー(外径 $70 \mathrm{~mm}$, 厚さ $0.15 \mathrm{~mm}$ )によ りみぞ加工し，温風乾燥炬によりモデルを軟化した状 態において，カミソリ刃によりき裂先端を鋭角に仕上 げる加工法を採用した。実験方法は $2 \cdot 1$ と同様であ る.試験片モデルを静的ねじり試験機に取り付けた。 てこ棒先端のおもりによる $7.84 \mathrm{~N}$ の荷重により $1.411 \mathrm{~N} \cdot \mathrm{m}$ のねじりモーメントを得た。試験片モデル を取り付けた静的ねじり試験機を温風乾燥炬内に設置 し, 図 4 に示す応力凍結サイクルによる光弾性応力 凍結法を適用し，等色線しま写真を得た。等色線しま 写真に外挿法を適用し, 開口形応力拡大係数 $K_{\mathrm{I}}$, 面内 せん断形応力拡大係数 $K$ 日を求めた ${ }^{(5)}$. 人工き裂先端 から最も遠い等色線しまにおいて，人工き裂先端から 最も遠い点を最遠点と呼ぶ。最遠点の等色線しま次数 $N_{m}$, 最遠点の距離 $r_{m}$, 光弹性感度 $\alpha$, 板厚 $t$, き裂を 基準とした最遠点角度 $\theta_{m}$ より $K_{1}, K_{n}$ は

$$
\begin{aligned}
& K_{\mathrm{I}}=\frac{N_{m}\left(2 \pi r_{m}\right)^{1 / 2}}{\alpha t\left[\left(\sin \theta_{m}+2 A \cos \theta_{m}\right)^{2}+A^{2} \sin ^{2} \theta_{m}\right]^{1 / 2}} \\
& K_{\mathrm{II}}=\frac{A N_{m}\left(2 \pi r_{m}\right)^{1 / 2}}{\alpha t\left[\left(\sin \theta_{m}+2 A \cos \theta_{m}\right)^{2}+A^{2} \sin ^{2} \theta_{m}\right]^{1 / 2}}
\end{aligned}
$$

$A$ は $K_{1, K \text { n }}$ 比であり

$A=\frac{K_{\mathrm{II}}}{K_{\mathrm{I}}}$

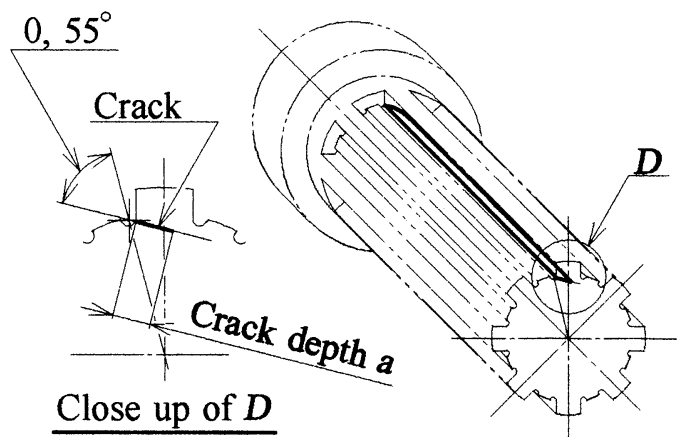

Fig. 7 Crack in spline shaft model

忘力拡大係数はき裂先端における応力状態を示す值 であり，值が高いほどき裂の進展が予測される，き裂 が進展することはき裂が深くなることであり，将来に おいて物体が破壊される。一般的に応力拡大係数は 0 $\sim 1.2 \mathrm{~N} \cdot \mathrm{m}^{-3 / 2}$ 程度を示す. 評価法として, $0 \sim 0.2 \mathrm{~N} \cdot \mathrm{m}^{-3 / 2}$ 程度であれば安全であり, $0.2 \sim 0.6 \mathrm{~N} \cdot \mathrm{m}^{-3 / 2}$ 程度は普 通, $0.6 \sim 1.0 \mathrm{~N} \cdot \mathrm{m}^{-3 / 2}$ 程度は危険, $1.0 \mathrm{~N} \cdot \mathrm{m}^{-3 / 2}$ 以上は極 めて危険な状態である。

$K{ }_{1}, K$ 嶰析後のスライス片に, 図 4 に示す応力凍 結サイクルを応用したアニーリングを施し, 応力解放 にともなう表面変形を促した，表面変形を利用し，反 射形コースティックス法により面外せん断形応力拡大 係数 $K$ mを求めた ${ }^{(6) \cdot(8)}$. 横弾性係数 $G$, コースティッ ク像の最大寸法 $Y_{\max }$, 試験片モデルからスクリーンま での距離 $Z_{o}$, 光源として発散光を使用した際の倍率 $\lambda よ り, K$ 的

$$
\begin{aligned}
& K_{\mathrm{II}}=0.5986 \frac{G Y_{m x^{3 / 2}}}{Z_{o} \lambda^{1 / 2}} \\
& \text { ここで倍率 } \lambda \text { は } \\
& \lambda=\frac{Z_{o}+Z_{i}}{Z_{i}} \ldots . . .
\end{aligned}
$$

$Z_{i}$ は焦点から試験片モデルまでの距離である.

\section{$2 \cdot 3$ 㛙き害れに関する破娆力学的挙動 一般に} スプライン軸は耐摩耗性を向上させるために熱処理が 施される. 熱処理を施す際，材料表面と材料内部にお ける温度差により焼き割れが発生する可能性がある。 微細な焼き割れは発見が困難である。焼き割れを再現 するために図 7 に示す $0^{\circ}$ 方向人工き裂を挿入したス プライン軸モデルを $2 \cdot 2$ と同様に製作した。光弾性 忘力凍結法により $K_{1, K} K_{\text {n, コースティックス法によ }}$ 


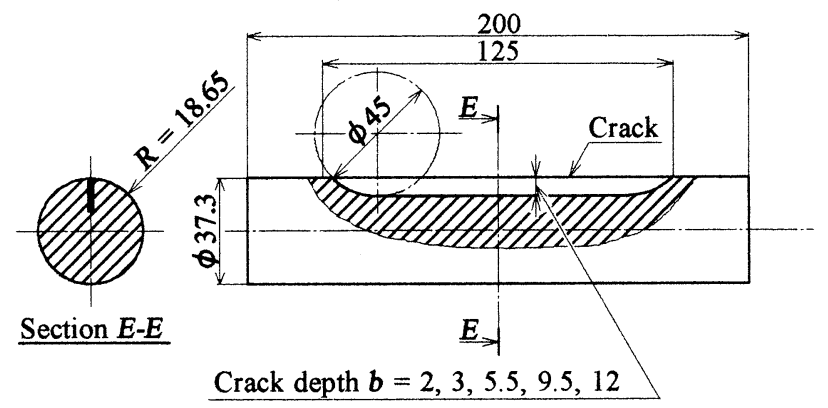

Fig. 8 Shaft model

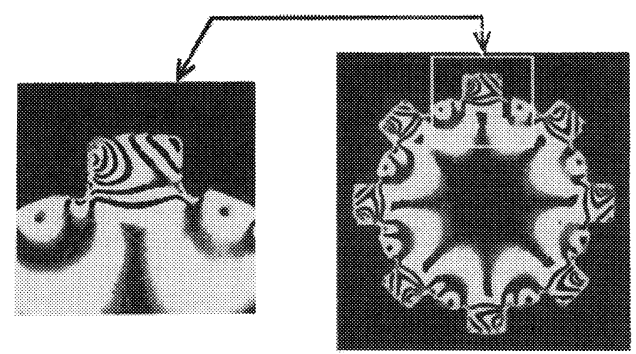

Fig.9 Isochromatic line $(Z=67.5 \mathrm{~mm})$

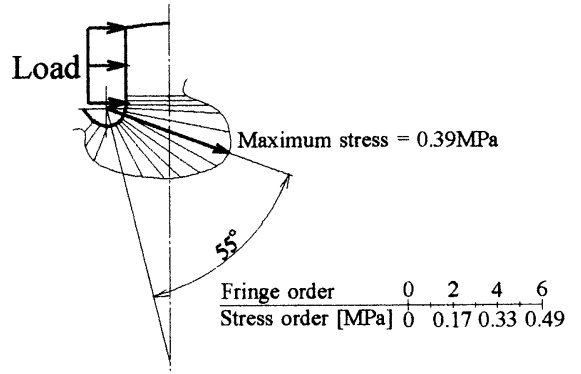

Fig. 10 Stress distribution $(Z=67.5 \mathrm{~mm})$

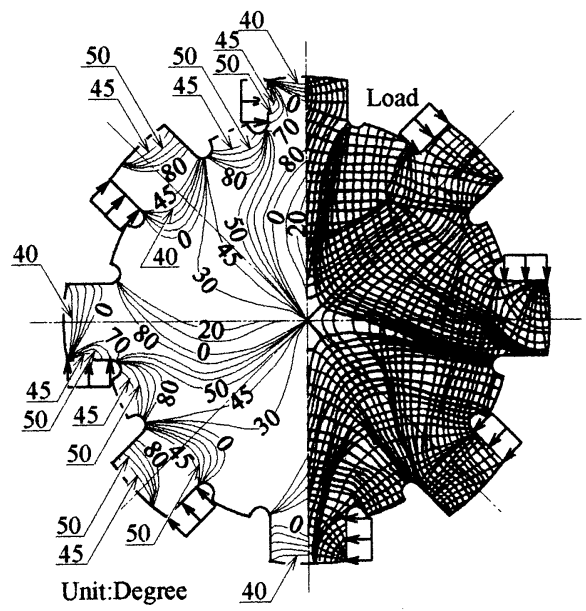

Fig.11 Isoclinic line and principal stress diagram $(Z=67.5 \mathrm{~mm})$
り $K$ 四を求めた．静的ねじり試験機のてこ棒先端に吊

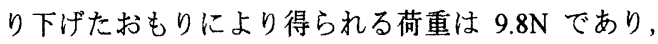
おもりにより得られるねじりモーメントは $1.764 \mathrm{~N} \cdot \mathrm{m}$ である。

予備実験として外周部に軸方向き裂(9)を有する円形 断面実軸モデル（図 8)について $2 \cdot 1$ と同様に実験し た. 静的ねじり試験機のおもりにより得られる荷重は $9.8 \mathrm{~N}$ であり，おもりにより得られるねじりモーメン 卜は $1.764 \mathrm{~N} \cdot \mathrm{m}$ である. 試験片モデルにコースティッ クス法を適用し，無次元化開口形忘力拡大係数 $F$ ! 求めた. 応力状態が安定している筒所の応力 $\sigma$, き 裂深さ $a$ より

$$
F_{\mathrm{I}}=\frac{K_{\mathrm{I}}}{\sigma_{0} \sqrt{\pi a}}
$$

諸条件により異なる值を示す応力拡大係数を正規化 した值が無次元化応力拡大係数である。評価法として 誤差が理論值に比して 8 \%以下であれば，実験方法 が有効であると判断する方法を採用した，き裂挿入方 法として,メタルソー(外径 $45 \mathrm{~mm}$, 厚さ $0.15 \mathrm{~mm}$ )によ りみぞ加工し，温風乾燥炬によりモデルを軟化した状 態において，カミソリ刃によりき裂先端を鋭角に仕上 げる加工法を採用した，き裂先端を鋭角に仕上げるこ とにより, 理論に合致した力学的挙動を得ることが可 能となる.

\section{3. 実 酫 果}

$3 \cdot 1$ スプライン軸に関する伈力解析 最も高い 主応力差が見られたスライス片の等色線しま写真を 図 9 に示し, 応力分布図を図 10 に示す. スプライン みぞ底円弧部に高い応力集中が見られた。スプライン 軸中心とみぞ底円弧中心を通過する直線を基準とした $55^{\circ}$ 方向が最大応力方向であることが分かった．等傾 線と主応力線図を図 11 に示す，軸方向距離 $Z$ に関す る各スライス片の最大応力を図 12 に示す. 他の部分 に比して 4 倍以上の高い応力がスプラインボス入ロ 


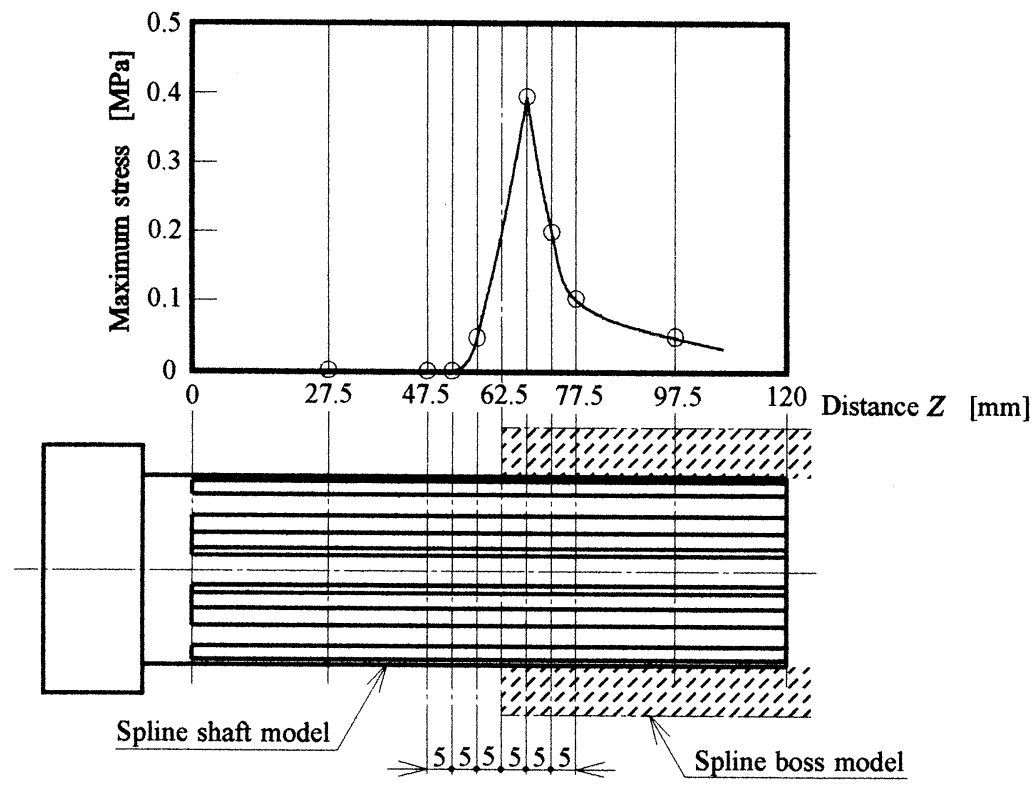

Fig.12 Relation between stress and distance $Z$

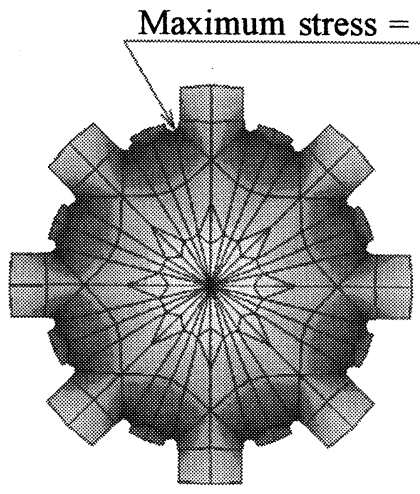

(a) Tresca stress distribution $(Z=62.5 \mathrm{~mm})$

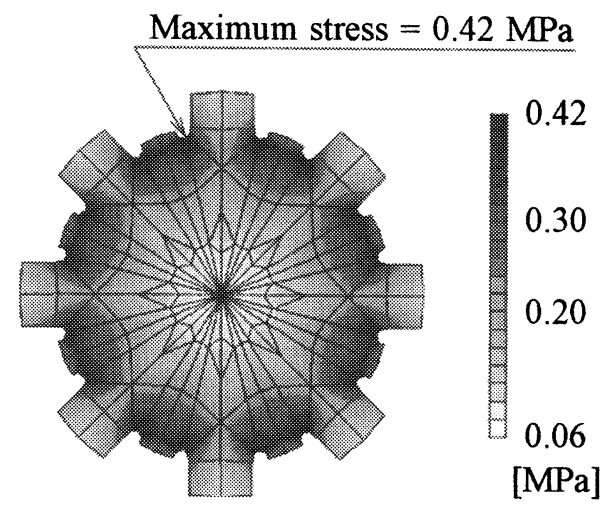

(b) Mises stress distribution $(Z=62.5 \mathrm{~mm})$

Fig.13 Stress distribution by finite element method

付近に見られた．信頼性を高めるために有限要素法に より応力集中位置を求め, 図 13 に示すトレスカとミ 一ゼスの応力分布を得た．スプラインみぞ底円弧部に 高い応力集中が見られ，有限要素法による結果は光弾 性法による結果に一致した，使用した有限要素解析ソ フトウエアが任意の位置における断面を表示できない ために，有限要素法と光弾性法の結果について $Z$ の 值がわずかに異なる。しかし光弾性法におけるスライ ス位置と同じ位直において，同様な状態であることを 確認した.

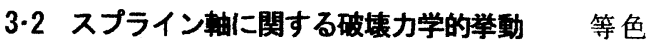
線しま写真を図 14 に示し， $K$ 州のコースティック像
を図 15 に示す.き裂先端に高い応力集中が見られた。 光弾性法により得られた 4 種き裂長さのき裂先端に おける $K_{1}$ と軸方向距離 $Z$ について図 16 に示す。ス プラインボス入口付近において高い値が見られた。き 裂先端における $K$ 咿微少であるためにき裂先端のし まループが明確でなく，測定不可能であった，き裂先 端における $K$ 四と軸方向距離 $Z$ について図 17 に示す. 他の部分に比して 2 倍以上の高い值がスプラインボ ス入口付近に見られた。一般的にき裂深さが大きくな るに従い，応力㹡大係数は高くなる。しかし比較的き 裂深さが大きな状態において，低い忘力拡大係数が図 16 に見られた，き裂先端における材料の降伏現象が原因 


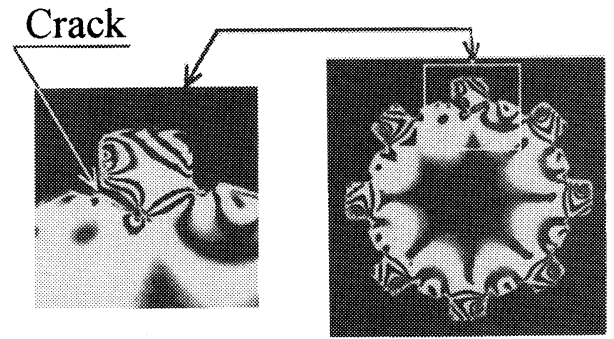

Fig.14 Isochromatic line of spline shaft model with crack (Crack angle $55^{\circ}, Z=67.5 \mathrm{~mm}$ )

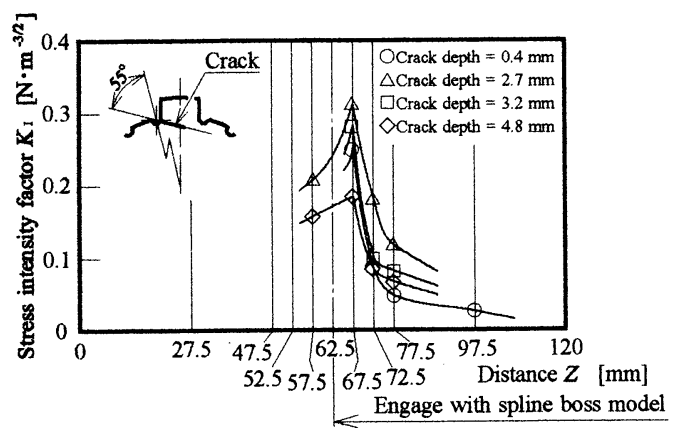

Fig. 16 Relation between stress intensity factor $K$ I and distance $Z$ ( Crack angle $55^{\circ}$ )

であると思われ，実験に適したき裂樑さは $2.7 \mathrm{~mm}$ 程 度であることが分かった。

\section{3 焼き害れに関する破嫃力学的挙動 等色線} しま写真を図 18 に示し, コースティック像を図 19 に示す，き裂先端における $K_{\mathrm{l}}, K_{\mathrm{n}}, K_{\mathrm{m}}$ と軸方向距離 $Z$ について図 20, 図 21, 図 22 に示す. いづれもスプライ ンボス入口付近において高い値が見られた．比較的き 裂深さが大きな状態において，低い応力抬大係数が図 20 に見られた．き裂先端における材料において降伏現象 が起きたものと思われる。

予備実験として外周部に軸方向き裂を有する円形断

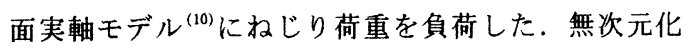

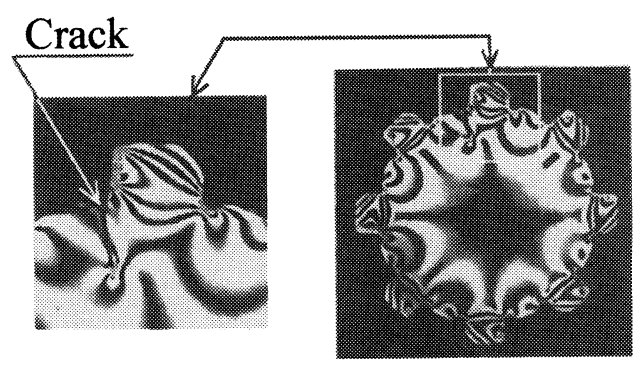

Fig. 18 Isochromatic line of spline shaft model with crack (Crack angle $0^{\circ}, Z=67.5 \mathrm{~mm}$ )

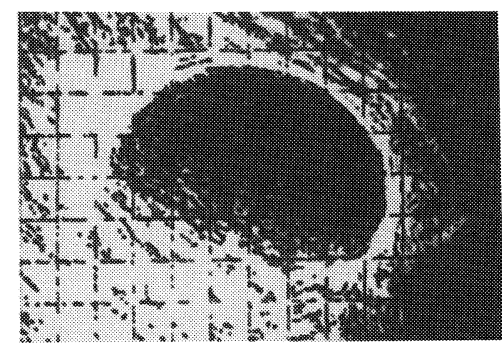

Fig. 15 Caustic pattern $K$ m of spline shaft model with crack (Crack angle $55^{\circ}, Z=67.5 \mathrm{~mm}$ )

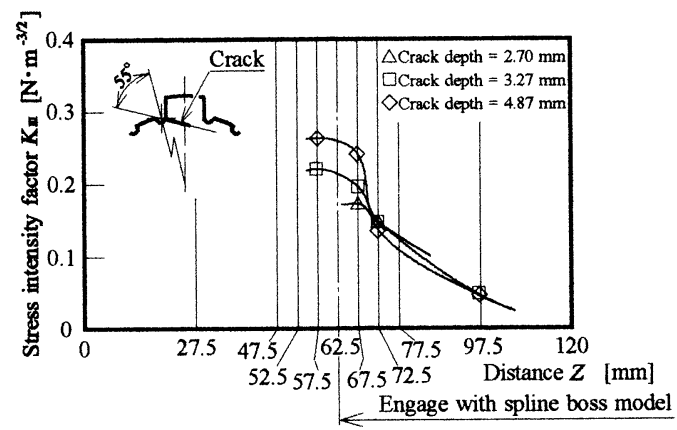

Fig. 17 Relation between stress intensity factor $K$ III and distance $Z$ (Crack angle $55^{\circ}$ )

開口形応力拡大係数を $F$ 、とし, き裂深さを $b$, 軸横 断面半径を $R$ とする. 図 23 にコースティックス法に より得られた $F_{1}$ と $b / R$ の関係を示す. コースティッ クス法による結果は Tweed-Rooke らの積分変換法 ${ }^{(11),(12)}$ による計算結果に関しておよそ $5 \%$ の誤差であり， コースティックス法により開口形応力拡大係数を解析 可能であることが分かった。

\section{4. 考察}

スプライン軸はスプラインボスにより変形が抑制さ れる. スプライン軸とスプラインボスの接触部に接触

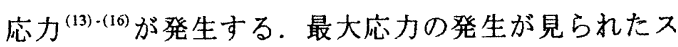

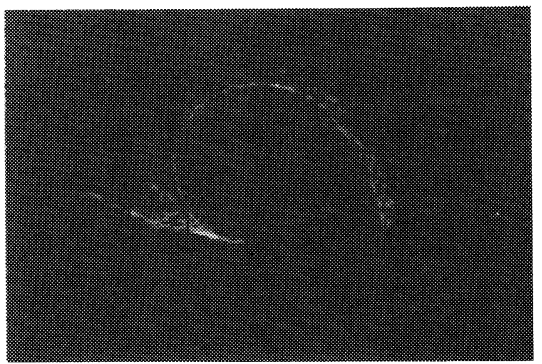

Fig. 19 Caustic pattern of spline shaft model with crack (Crack angle $0^{\circ}, Z=67.5 \mathrm{~mm}$ ) 


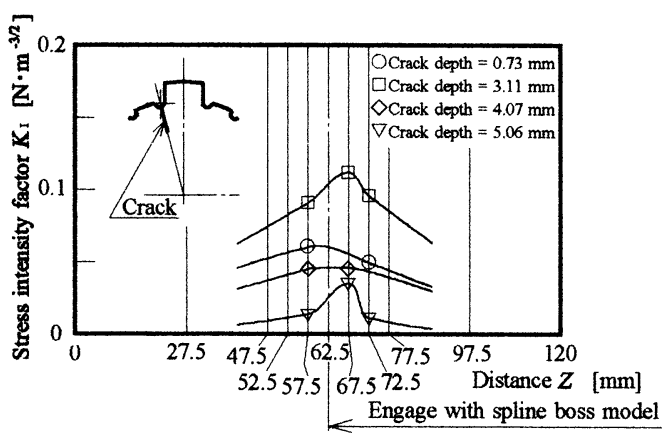

Fig. 20 Relation between stress intensity factor $K$ I and distance $Z$ ( Crack angle $0^{\circ}$ )

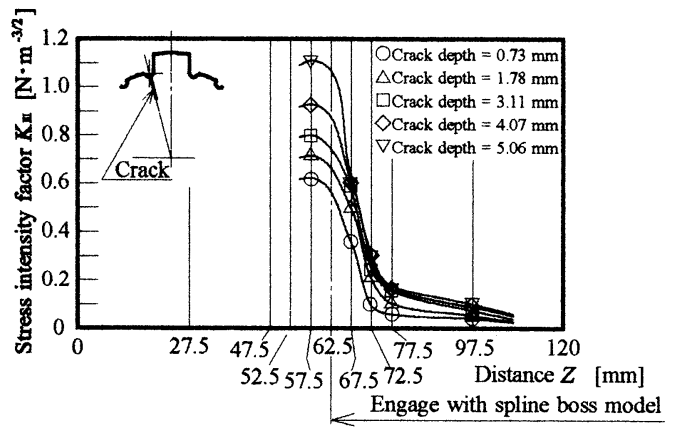

Fig. 22 Relation between stress intensity factor $K$ m and distance $Z$ (Crack angle $0^{\circ}$ )

プラインみぞ底円弧部は，スプラインボスに接触しな い部分であり，変形が抑制されない，スプライン軸全 面がスプラインボスと接触する形状に改良することに より,スプラインの破壊事故を防止できると思われる.

\section{5. 䊅 言}

ねじり荷重を負荷されるスプライン軸に関して, 光 弾性法,コースティックス法, および有限要素法によ り力学的挙動を調べ, 次の知見を得た.

(1)スプラインボス入口付近のスプライン軸みぞ底円 弧部に最大応力が見られた。 スプラインボス入口付近 のスプライン軸横断面上において，スプライン軸中心 とみぞ底円弧中心を通過する直線を基準とした $55^{\circ}$ 方向が最大応力方向であることが分かった．

(2) $55^{\circ}$ 方向き裂先端における開口形応力拡大係数 $K$, 面内せん断形応力拡大係数 $K$ n, 面外せん断形応力 拡大係数 $K$ 四について，いづれもスプラインボス入口 付近に高い值が見られ，特に $K$ mが顥著である．

(3) $55^{\circ}$ 方向き裂先端において，K１についてき裂深さ $2.7 \mathrm{~mm}$ において高い值が見られ，Knについて影響は

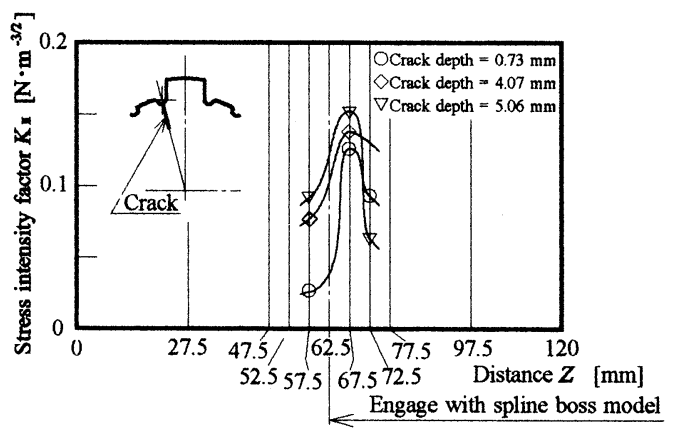

Fig.21 Relation between stress intensity factor $K$ II and distance $Z$ (Crack angle $0^{\circ}$ )

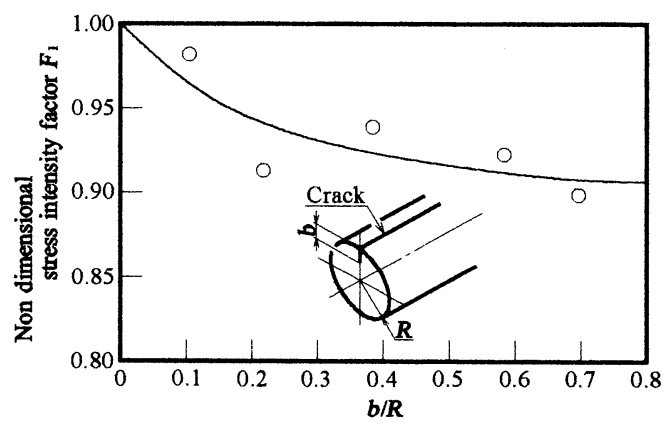

Fig.23 Relation between non dimensional stress intensity factor $F I$ and $b / R$

微少であり，Kmについてき裂が深くなるに従い，高 くなる傾向である.

(4)焼き割れによるき裂先端における $K_{1, K}, K, K$ 亚につ いて，いづれもスプラインボス入口付近において高い 值を示した。

（5）焼き割れによるスプライン軸中心方向き裂に関し て，K、についてき裂樑さ $3.11 \mathrm{~mm}$ において高い值が 見られ， $K$ п, $K$ 四についてき裂が深くなるに従い，高 くなる傾向が見られた。

\section{考文献}

(1) Hiroyuki Yoshitake:Experiment in Spline Shaft by Photoelastic Method,Journal of the Japan Society of Mechanical Engineers, Vol.64,No.508,(1961), pp.42-47.

(2) Hazime Nakazawa:On the Torsion of the Spline Shafts,Transactions of the Japan Society of Mechanical Engineers, Vol.25,No.155,(1959), pp.643-650.

(3) Katsumi Sakaguchi and Masakatsu Kubo:Destruction on the Spline Shaft by Torsion, Research on the Mechanical Engineers, Vol.29,No.5, (1976) ,pp.716. 
(4) S.R.White and A.B.Hartman:Effect of Cure State on Stress Relaxation in 3501-6 Epoxy Resin,Journal of Engineering Materials and Technology, No.119,(1997),pp.262-265.

(5) Tsutomu Ezumi and Susumu Takahashi:Stress intensity Factors for the Mixed Mode in Rotating Disks Having Branched Cracks, Transactions of the Japan Society of Mechanical Engineers, Vol.54,No.505,A (1988),pp.1800-1806.

(6) Dafung $\mathrm{Wu}$, Susumu Takahashi and Tsutomu Ezumi:Experimental Study of Stress Intensity Factors $K$ m of a Three-Dimensional Crack by the Method of Caustics, Transactions of the Japan Society of Mechanical Engineers, Vol.56,No.527,A (1990), pp.53-58.

(7) Youngmin Ha,Tsutomu Ezumi and Susumu Takahashi:Stress Analyses of Hollow Cylinder with Inner Cracks Subjected to Torsion,Transactions of the Japan Society of Mechanical Engineers, Vol.63,No.609,A (1997),pp.47-52.

(8) Youngmin Ha,Tsutomu Ezumi and Susumu Takahashi:Computation of Stress Intencity Factors $K_{1}, K$ n and $K$ m of Hollow Cylindrical Bars with Three-Dimensionally Inclined Cracks,Proceedings of the Japan Society for Photoelasticity,Vol.19,No.1, (1999),pp.1-7.

(9) Sun-ho Choi,Jae-do Kwon and Hideo Kitagawa:An Analysis of the Stress Intensity Factor $K$ m of a Longitudinal Surface Crack by the Displacement Freezing Analogy Method,Transactions of the Japan Society of Mechanical Engineers,Vol.52,No.484,A (1986), pp.2653-2661

(10) Weili Cheng and Iain Finnie:The Single Slice
Method for Measurement of Axisymmetric Residual Stresses in Solid Rods or Hollow Cylinders in the Region of Plane Strain,Journal of Engineering Materials and Technology,No.120,(1998), pp.170-176.

(11) D.P.Rooke,J.Tweed:The stress intensity factors of a radial crack in a finite rotating elastic disc,Selected Papers on Crack Tip Stress Fields,University of Maryland, (1997),pp.162-167.

(12) D.P.Rooke,J.Tweed:The stress intensity factor of an edge crack in a finite rotating elastic disc,Selected Papers on Crack Tip Stress Fields, University of Maryland, (1997),pp. 168-172.

(13) Susumu Takahashi,Akira Shimamoto and Fumio Nogata:Stress Analysis of Contact Problem by Two-dimensional Photoelastic Method, Non-destructive Inspection,Vol.25,No.8,(1976), pp.478-483.

(14) Tetsuo Noguchi and Tsutomu Ezumi:The Best Dimensional Standard Analysis Concerning Center Hole in Dabo, International Journal of Modern Physics B,World Scientific Pub. Co. Pte Ltd.,Vol.17, No.3\&4, (2003),pp.821-825.

(15) Tetsuo Noguchi and Tsutomu Ezumi:Simulation by Comparison between Photomechnics and Finite Element Method for Center Hole,Transactions of the Japan Society of Mechanical Engineers,Vol.68, No.674,A (2002),pp.4-11.

(16) Tetsuo Noguchi and Tsutomu Ezumi:Influence on the Tensile Load in Inclination Elliptic Inclusion, Transactions of the Japan Society of Mechanical Engineers, Vol.70,No.690,A (2004), pp. 105-112. 